\title{
Effect of Hand-Eye Coordination on the Capability of Children Object Control
}

\author{
Zainul Johor, Romi Candra*, Willadi Rasyid, Arie Asnaldi, Oktarifaldi, Syahrial Bakhtiar \\ Faculty of Sport Science \\ Padang State University \\ Padang, Indonesia \\ *romicandra62@gmail.com
}

\begin{abstract}
This study aims to see the effect of hand-eye coordination on the ability of child control objects. The population in this study were all PAUD students aged 5 to 6 years in Padang Pariaman District, a random sampling technique totaling 42 children. The instrument used to obtain data on the hand-eye coordination of children aged 5 to 6 years is to conduct anthropometric tests measuring height and weight. In contrast, the ability of the object of child control is obtained through the Test of Gross Motor Development-2 (TGMD-2). Based on the results of the research conducted, there is the influence of hand-eye coordination on the ability of a child's control object with a rcount value of $0.428>$ table of 0.304 and a significant value (Sig) of 0.007 smaller than the probability of 0.05 . The results of this study indicate that the coordination of their hands influences the ability of object control possessed by children aged 5 to 6 years in Padang Pariaman Regency. The better hand-eye coordination criteria they have, the better the ability of the control objects they can display.
\end{abstract}

\section{Keywords-Hand-eye coordination, object control ability}

\section{INTRODUCTION}

Early childhood education basically includes all the efforts and actions taken by educators and parents in the process of care, care and education for children by creating an environment so that children can explore experiences and provide opportunities for them to know and understand the learning experiences gained from the environment, through ways observing, imitating and experimenting repeatedly and involving all the potential and intelligence of children. In the Republic of Indonesia Education and Culture Regulation Number 84 Article 1 Paragraph (1) of 2014 concerning the Establishment of Early Childhood Education Units [1].

The target of early childhood education (PAUD) according to the law is 0 to 6 years, and can be implemented either through formal, non-formal and / or informal education. PAUD is the initial stage in the process of children's education to enter further education with a higher level of learning material. At 5 years is a golden period of child development, both for physical and motor development as well as cognitive, psychological and social development of children [2]. The development and growth of this child can only develop properly if we apply the concept of learning while playing by doing physical activities.
In order to improve the skills of PAUD teachers the government has made several programs such as workshops and training in several areas. The implementation of this activity is based on the concerns of activists and experts working in the field of kinesiolgi, PAUD and the government that it seems that the basic mobility abilities of children in Indonesia are declining. One indication is that according to WHO reports there are around $30 \%$ of children in Indonesia suffering from obesity. In addition, there is also evidence that shows that the level of physical activity of children and adolescents throughout the world is down and this generation of children is less active and fatter than other generations of children [3].

The ability to coordinate is one component of physical fitness that is related to one's skills, both hand and eye coordination. It can be said to have the ability of skills illustrated from how well the coordination possessed. Thus someone who has good coordination skills will be easy to learn a variety of movement skills. teachers are expected to be able to improve children's coordination skills while being able to find the most appropriate learning methods to help children who have poor coordination skills.

Hand-eye coordination is the ability of the vision system to coordinate information received through the eye to control, guide, and direct the mind of the hand in completing a given task, such as handwriting or catching a ball [4]. Hand eye coordination is one of the human abilities that is needed and can affect various aspects of daily life including school, daily life activities and social interactions [5]

Therefore, researchers are interested in conducting research related to things that are suspected of having an effect on the ability of object control of children in PAUD Pembina Padang Pariaman Regency.

\section{BASIC MOTION ABILITY AND EYE COORDINATION}

\section{A. Basic Motion Ability}

Basic mobility is a very basic mobility that must be possessed by a child at an early age in order to make a series of more complex movements in the future. Basic motion skills are considered as the basis for competence [6]. The basic motion ability is divided into two big groups, namely the ability of the control object and locomotor [5]. The locomotor ability is the motion that 
moves the body from one point to another while the ability of the dick object is the object manipulation movement.

The object of control is the ability to improve the performance of muscles to make a movement, and has a good ability to make controlled and precise movements with an object. Object control skills consist of (1) throwing (overarm throw) (2) kicking a ball (kicking), (3) kicking a ball that is self-propelled (punting), (4) running with the front legs (leap), (5) hitting the ball with a tool (racket) in a state not moving from above (overarm stricking a stationary ball). So, the ability of a control object is the ability possessed by a child to be able to control or control objects that are commonly used in realizing basic motion skills, such as holding, throwing, catching, hitting and kicking. The portion of skills possessed by each child for mastering the ability of this control object is different. This difference in ability is influenced by many factors, including: eye-hand coordination, body mass index, heredity, gender, social environment, parents' suh patterns, parental knowledge, and children's confidence.

This object control ability measures the ability to throw, catch, reflect, hit, roll and kick a ball based on the TGMD-2 instrument for children aged 5 to 6 years that was conceived by Ulrich. Every skill displayed by students will be captured on video. The assessment is done by coding the video. Each skill assessed has several characteristics that must be fulfilled by students. Every movement that matches the characteristics contained in the assessment sheet will be given a value of 1 and the wrong will be given a value of 0 . For each skill that is assessed students will be given 3 times the opportunity, 1 time for the experiment and 2 times for the assessment.

In the TGMD-2 test, there are some equipment needed, including plastic hitters, tennis balls, plastic balls with a diameter of $8 \mathrm{~cm}$, plastic balls with 8 inch size, tennis balls, basketball, meter, buffer ball and upright cone. All research data and equipment are stored in the archive room.

\section{B. Hand Eye Coordination}

Coordination is also called the ability to carry out an activity quickly and efficiently [7]. Eye-hand coordination is the ability of the eyes and hands possessed by someone in carrying out a physical task at the same time. Hand eye coordination is one of the human abilities that is needed and can affect various aspects of daily life including school, daily life activities and social interactions [8]. The results show that eyehand coordination will develop better as children age [9]. This development occurs when children aged 8 to 16 years because more and more diverse tasks performed indirectly will improve the quality and development of the child's eye-hand coordination ability. These activities can be in the form of catching and throwing, if a child can do these activities with ease without significant obstacles, in general the child is considered to have good eye-hand coordination.

So that eye-hand coordination can develop optimally, the participation of parents is very important. Providing catching and throwing exercises in daily activities will certainly have a good effect on the eye-hand coordination of children at this age. One example is when children learn to draw, they hold a pencil and use their hands to write by making various strokes on paper or moving their feet to walk towards people around them [10].

The ability of hand eye coordination possessed by PAUD students is obtained through the catching and throwing test which is a sub-test on the M-ABC test. Students are asked to do throwing and catching but using a bean bag or a bag filled with green beans. The scorer is counted the number of captures that were successfully carried out by students by hand. To throw will be counted how many throws according to the target that can be done by students. Later it will be written in the M-ABC sheet and then it will be calculated based on the norm table

\section{The DATA ACQUISITION SETUP}

The instrument used to obtain data on the eye eye coordination of PAUD students is the MABC_2 sub-test, which is catching and throwing done using a bean bag or bag containing beads, functioned as an object thrown to the target and the object to be captured. Students will be asked to throw bean bags to the target 10 times and catch bean bags also 10 times.

While the ability of child control objects is obtained through the Test of Gross Motor Development-2 (TGMD-2) consisting of strike, catch, dribble, kick, throw and roll. Each skill will be performed 3 times by students. The first try is as preparation while the second and third try will be assessed. For each of these abilities has each criterion that must be met by students. If the movements carried out in accordance with each criterion, then each value will be given 1 if wrong will be given 0 . In data collection there are several tools used, including; tennis balls (1), plastic bats (2), ball supports (3), basketball (4), soft ball (5),

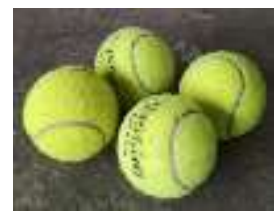

Picture 1. Tennis ball

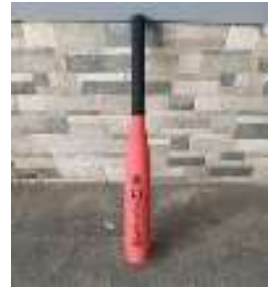

Pictur 2: The bat

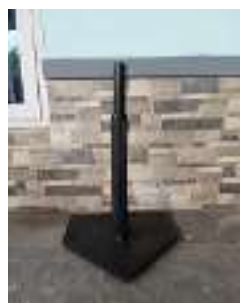


Picture 3. Ball support

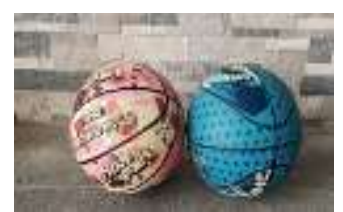

Picture 4. Soft basketball

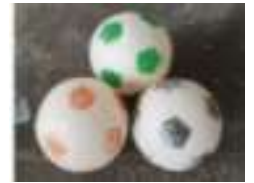

Picture 5. Plastic foot ball

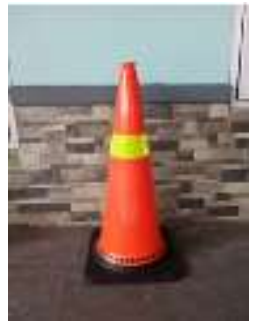

Picture 6: Traffic cone

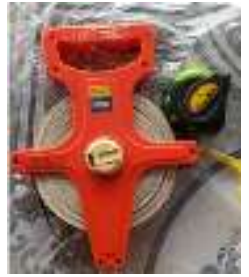

Picture $7:$ meter

\section{THE DATASET}

Data on the ability of PAUD student object control in Padang Pariaman District were taken 2 repetitions for all children for each skill tested. Data from the test is stored in video format. The grading of the ability of this control object is based on the TGMD-2 evaluation sheet. If a child succeeds in fulfilling one of the criteria, then a score of 1 will be given and if not, a score of 0 will be given, that is the rating for each criterion in each skill. For each skill assessed each child is asked to do it 3 times, the first try is as preparation and the second and third try to be assessed.

Then for the child's hand eye coordination data is obtained with 1 trial for each movement and this data is stored in the form of a test sheet. This hand eye coordination data was obtained through a catching and throwing test, which is throwing a ball using a bean bag containing beads. This test is given to children aged 5 to 6 years. The number of students involved was 42 consisting of 24 women and 18 men.

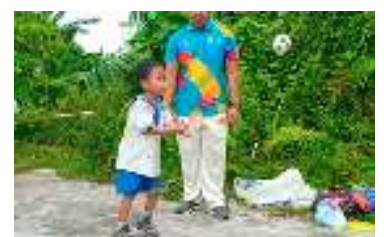

Picture 8. Illustration of catching a ball
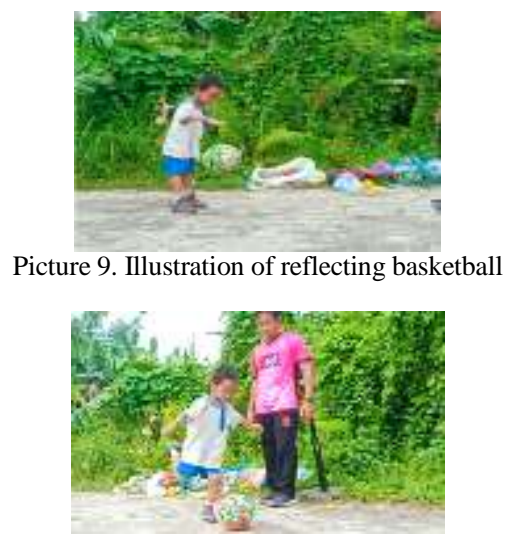

Picture 10. Illustration of kicking a ball

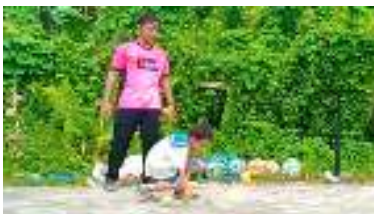

Picture 11 :. Illustration of rolling a ball

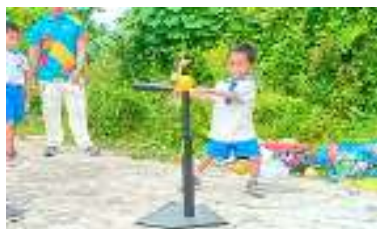

Picture 12 :. Illustation of hitting a ball

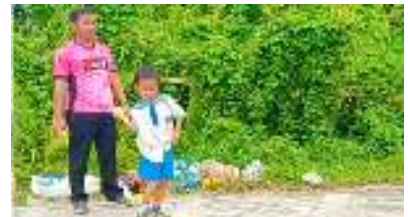

Picture 13. Illustration of throwing a ball

\section{CONCLUSIONS}

The data obtained in this study have a fairly good quality because it uses a valid instrument and all the criteria of control object skills that have been assessed have been coded by experts and $\mathrm{m}$-abc subtest. The study was conducted on paud students aged 5 to 6 years. It is recommended that parents and teachers be able to educate and pay attention to the hand eye coordination that children have in order to support the ability of the object of control that they have. In the future we will try to apply a learning model that is in line with the paud curriculum in indonesia. Further research needs to be done related to variables that affect the ability to control subjects of a child with a wider sample.

\section{REFERENCES}

[1] Peraturan Menteri Pendidikan Dan Kebudayaan Republik Indonesia Nomor 84 Tahun 2014 Tentang Pendirian Satuan Pendidikan Anak Usia Dini. 2014.pp.10-27.

[2] Grantham-McGregor S, Cheung YB, Cueto S, Glewwe P, Richter L, et al. "Developmental potential in the first 5 years for children in developing countries". Lancet 369: 2007.pp.60-70 
[3] Goodway, Jacqueline D, Famelia Ruri \& Bakhtiar, Syahrial. 2014. "Future Directions in Physical Education \& Sport: Developing Fundamental Motor Competence in the Early Years Is Paramount to Lifelong Physical Activity". Asian Social Science; Vol. 10, No. 5; 2014 ISSN 1911-2017 E-ISSN 1911-2025 Published by Canadian Center of Science and Education

[4] Flier. "Motor coordination problems in children and adolescents with $A D H D$ rated by parents and teachers: effects of age and gender. $\mathrm{J}$ Neural Transom. 2010; 115:211-220.

[5] B, Syahrial. "Merancang Pembelajaran Gerak Dasar Anak. Padang; UNP Press. 2015.pp.32-55.

[6] Liu T, Getchell N. Pope ML. "Object-control skills in Hispanic preschool children enrolled in Head Start". PMID: 21466092 DOI: 10.2466/10.11.17.24.PMS.112.1. 2011.pp.193-200

[7] Wardana Pramoda, Furqon M Hidayatullah, Kiyatno. "The Influence of Learning Approach and Hand-Eye Coordination on the Free Throw Results in Basketball Games". International Journal of Recent
Engineering Science (IJRES),ISSN: 2349-7157, Vol.4 Issue 4 July to August 2017

[8] Senthil Kumar Srinivasan. "Significance Of Mental Rehearsalon Hand-Eye Coordination". THESES. 2011.pp.12-21.

[9] Ada Wai, Wing Ma \& Lily Qu. "The Effect of Exergaming on EyeHand Coordination among Primary School Children: A Pilot Study". Copyright ( $\odot 2016$ by authors and Scientific Research Publishing Inc . Advances in Physical Education, 6, 2016. 99-102.

[10] Arun Kumar Nayak. "Effect Of Hand-Eye Coordination On Motor Coordinative Ability Of Tribal Adolescents". International Journal of Physical Education, Sports and Health 2015; 2(2): 328-330. P-ISSN: 2394-1685E-ISSN: 2394-1693 Impact Factor (ISRA): 4.69 IJPESH 2015; 2(2): 328-330. 